\title{
Setting up HIV serology for the Karonga leprosy vaccine trial in Malawi
}

\author{
M A SHAW, A C TURNER, J M BLACKWELL, \\ P E M FINE \& J M PONNIGHAUS* \\ London School of Hygiene and Tropical Medicine, Keppel Street, \\ London WCIE 7HT; *Lepra Evaluation Project, PO Box 46, \\ Chilumba, Malâ̂i
}

Accepted for publication 17 September 1990

\begin{abstract}
Summary As part of the leprosy vaccine trial taking place in Karonga District, Northern Malawii, it is essential to establish whether the presence of HIV infection in the population is affecting the incidence rate or clinical presentation of leprosy or the effectiveness of the trial vaccines. To obtain the appropriate information, a rapid and economical HIV testing protocol, which could be performed in a rural laboratory and would be robust under variable environmental conditions, had to be developed. This paper reports on the development/evaluation phase of a multitest protocol based on commercially available particle agglutination and ELISA anti-HIV antibody detection kits. The protocol was devised by first evaluating a range of kits in London using a battery of African and non-African sera and then field testing 1455 sera in Malawi, which included 184 sera from leprosy patients and 60 sera from syphilis patients to check for cross-reactivity. According to the protocol developed, all sera are screened initially both by indirect ELISA (Organon) and using a rapid and economical modification of the Serodia particle agglutination test. Positives are retested using both a competitive ELISA (Wellcome or Behring) and the standard Serodia particle agglutination test. The validity of this multitest protocol was confirmed by Western blotting a large sample of the positive and negative Malawian sera in London. Factors affecting kit selection, and problems associated with individual kits, are discussed. While the specific multitest protocol developed for Malawi might not be suitable for every project, the principle of developing economical alternatives to Western blotting is an important consideration for any field investigation of HIV.
\end{abstract}

\section{Introduction}

It is well documented that individuals with HIV infection are at increased risk of certain mycobacterial diseases, in particular tuberculosis and the so-called atypical mycobacterioses. ${ }^{1,2}$ The possibility that HIV might affect incidence rates or clinical presentation of leprosy has been conjectured, but is still an open question. ${ }^{3-5}$ This issue has become of 
critical importance to the antileprosy vaccine trial currently being carried out in Karonga District, Northern Malawii. ${ }^{6}$ HIV infection has been recognized in Malawi at least since 1985. ${ }^{7-12}$ Given that HIV infection is known to be endemic in the vaccine trail population, interpretation of the data obtained from the trial would be compromised in the absence of information on HIV infection and its implications for leprosy incidence and vaccine effect. For this reason a proposal to carry out a case-control study of leprosy and HIV infection, in the context of the vaccine trial, was submitted to the Malawi government, was approved and began in 1988. The study entails the comparison of HIV status between leprosy patients and control groups matched for age, sex and area of residence.

The case-control study involves carrying out HIV serological assays on both leprosy cases and controls selected from within the population of Karonga District. The results of this study will be reported at a later date, but this paper describes steps undertaken to set up the laboratory protocol for work carried out in Malawi. It is felt that our experience may be of help to other researchers contemplating similar studies. It should be emphasized that the samples used in the preliminary studies reported here were highly selected, hence prevalence rates should not be inferred from the frequencies obtained.

\section{Review of methods available for HIV testing}

A number of methods of detecting antibodies to HIV, the usual criterion used for infection, are currently available (Table 1). The most widely used diagnostic kits are those employing the ELISA technique. These may either be of the sandwich type where specific HIV antibodies are detected with a second labelled antiglobulin reagent (e.g. Organon, DuPont, Elavia) or of the competitive type where specific HIV antibodies compete with labelled anti-HIV (e.g. Wellcome, Behring). Western blotting works in principle as a sandwich ELISA but in this case viral proteins are separated by SDS polyacrylamide gel electrophoresis and transferred to nitrocellulose prior to incubation with test sera, so that antibodies to individual viral components may be detected (e.g. Biorad, Elavia, Du Pont). Increasing in popularity are the particle agglutination tests in which gelatin (Serodia) or latex beads (Cambridge Biosciences) are coated with viral antigens for incubation with sera. In addition to the above methods are immunofluorescence and slide tests (e.g. Karpas).

The most widely used method of determining HIV status, at least in areas of low prevalence, has been to screen sera by ELISA. Positive results may be repeated and then tested by Western blot, which has been taken as a standard. ${ }^{13,14}$ Antibodies detected by Western blot include antibodies to core antigens p17, p24 and p55 (gag gene products) and to envelope glycoproteins gp41, gp120 and gp160 (env gene products). ${ }^{15}$ Although diagnosis of HIV positivity is now commonly made if antibodies to both gag and env products are observed, ${ }^{13,14}$ a serum containing anti-p24 alone may indicate HIV positivity. ${ }^{13,16}$ In European studies seroconversion is generally found to be accompanied by the appearance of anti-p24 followed by anti-p55 several weeks after infection. ${ }^{16-18}$ Western blots highlight changing antibody profiles with the onset of AIDS (in particular the decline of anti-core antibodies in Europeans). ${ }^{15,17,19}$ In contrast, false-positive or 'indeterminate' sera containing only antibodies to gag gene products have been identified, ${ }^{20-27}$ some by repeated sampling over a period of time ${ }^{20,22}$ and some by a failure to culture virus. ${ }^{21}$ Additional problems include cross-reactions between viral proteins and 
Table 1. Summary of the major types, suppliers, advantages and disadvantages of kits available for the detection of anti-HIV antibodies.

\begin{tabular}{|c|c|c|c|}
\hline Type & Suppliers (e.g.) & Advantages & Disadvantages \\
\hline \multirow[t]{4}{*}{$\begin{array}{l}\text { Sandwich } \\
\text { ELISA }\end{array}$} & & $\begin{array}{l}\text { Printed records, suitable for } \\
\text { plasma. }\end{array}$ & Requires a plate reader. \\
\hline & Organon Teknika & $\begin{array}{l}\text { Uses dilute samples, suitable } \\
\text { for filter papers. }\end{array}$ & \\
\hline & $\begin{array}{l}\text { Diagnostics Pasteur } \\
\text { (ELAVIA) }\end{array}$ & $\begin{array}{l}\text { Control well for each sample, } \\
\text { different viral isolate (LAV). }\end{array}$ & \\
\hline & Abbott & & $\begin{array}{l}\text { Bead technology-requires } \\
\text { specialized equipment. }\end{array}$ \\
\hline \multirow[t]{3}{*}{$\begin{array}{l}\text { Competitive } \\
\text { ELISA }\end{array}$} & & Printed records. & $\begin{array}{l}\text { Uses more sample, may not } \\
\text { detect all variants (e.g. } \\
\text { HIV2). }\end{array}$ \\
\hline & Behring & & \\
\hline & Wellcome & Suitable for filter papers. & $\begin{array}{l}\text { False negatives with plasma, } \\
\text { peroxidase problems, supply } \\
\text { problems. }\end{array}$ \\
\hline \multirow[t]{4}{*}{$\begin{array}{l}\text { Particle } \\
\text { agglutination }\end{array}$} & & $\begin{array}{l}\text { High sensitivity, negative } \\
\text { control for each sample. }\end{array}$ & No printout of results. \\
\hline & Cambridge Biosciences & & No UK agent. \\
\hline & Fujirebio (Serodia) & $\begin{array}{l}\text { No major equipment } \\
\text { required }\end{array}$ & $\begin{array}{l}\text { Not advised for testing } \\
\text { plasma samples. }\end{array}$ \\
\hline & $\begin{array}{l}\text { Edgware modification of } \\
\text { above }\end{array}$ & Low cost. & $\begin{array}{l}\text { Requires centrifuge, limited } \\
\text { lif espan of particles. }\end{array}$ \\
\hline \multirow[t]{2}{*}{ Slide tests } & Karpas & & $\begin{array}{l}\text { Background problems with } \\
\text { African sera. }\end{array}$ \\
\hline & Organon & & $\begin{array}{l}\text { Requires a fluorescent } \\
\text { microscope. }\end{array}$ \\
\hline \multirow[t]{2}{*}{ Western blot } & & $\begin{array}{l}\text { Gives qualitative } \\
\text { information. }\end{array}$ & $\begin{array}{l}\text { High cost, difficult to } \\
\text { interpret, nonspecific bands. }\end{array}$ \\
\hline & $\begin{array}{l}\text { Biorad, DuPont, } \\
\text { Diagnostics Pasteur }\end{array}$ & & \\
\hline
\end{tabular}

The various comments in this table obtained from the literature and by observation of the kit instructions are meant as rough guides only, and should be interpreted in the context of specific applications envisaged.

antibodies to other retroviruses or to other proteins in the HIV preparation. ${ }^{28}$ Advice as to the appropriate protocol for testing such sera has varied..$^{26,29}$

The available tests differ in the number of false positives they detect and in their ability to detect seroconverters and diseased individuals. These differences are associated with the virus preparation and methodology employed. ${ }^{22,23,30,31}$ However, as techniques have become more sensitive, ${ }^{32,33}$ in some cases even more sensitive than the Western blot, it is becoming accepted practice for other tests to replace the Western blot for confirmation. This has been proposed both for Europe/USA ${ }^{32,34}$ and for Africa. ${ }^{35-37}$ A combination of two tests based on different methodologies (e.g. ELISA and particle agglutination tests) reduces the chance that nonspecific factors will interfere with both tests and result in a false positive. ${ }^{33}$ Some studies have given equal weight to each test. ${ }^{32}$ Alternatively, an 
initial screen using the most sensitive test can be followed by a second highly specific test on positive samples only. Problem sera (e.g. positive by the more sensitive test, negative by the more specific test) may then be analysed by Western blotting. ${ }^{36,38}$

Western blots are not ideal for Africa, ${ }^{30,39}$ where the incidence of HIV is high, because of their cost (e.g. Biorad costs $£ 12.80$ per sample) and because blot profiles of positive African sera may differ from those of Western sera. ${ }^{40}$ False-positive or uninterpretable results associated with apparent anticore antibodies and nonspecific weak bands have been identified. ${ }^{35,40,42}$ Many evaluations of ELISA and particle agglutination tests have been reported (e.g. ${ }^{32,43-49}$ ), giving details of sensitivity, ability to detect seroconverters ${ }^{33,50}$ and specificity together with reactions with panels of problem sera. ${ }^{22}$ However, these surveys, carried out using sera from Europe and America, have not always reached similar conclusions. Since most commercial kits are still evolving (e.g. the use of recombinant peptides is now increasing at the expense of whole virus preparations), reported evaluations are not necessarily appropriate to current kits. Whereas there has been much discussion as to the suitability of various tests for Africa, ${ }^{30,39,40,42,51}$ there have been few comprehensive evaluations. ${ }^{35-37,52-55}$

\section{Selection of tests for evaluation}

Our selection of tests to be evaluated for HIV testing in Malawi was determined in part by the circumstances in which the work was to be carried out. The project laboratory in Chilumba has carried out routine microscopy on slit skin and sputum smears, sputum culture, and syphilis serology for several years. Located in a rural area, many reagents must be shipped from London. Distilled water is available, but electricity is generated for only 8 to 9 hours per day. Ambient temperature in the laboratory varies between $28^{\circ} \mathrm{C}$ and $36^{\circ} \mathrm{C}$, resulting in suboptimal performance of refrigerators and freezers. The technicians had very limited experience in techniques relevant to HIV testing.

The following specific issues were considered when selecting and evaluating tests (see Tables 1 and 2):

1 We reviewed the literature on HIV tests employed in countries in Central, East and South Africa and found that a variety of tests had been used: 'Organon' in Tanzania ${ }^{56}$ and Rwanda, ${ }^{57-59}$ 'Wellcome' in Zambia ${ }^{4,60}$ and Uganda, ${ }^{61,62}$ and 'Abbott' in Zimbabwe ${ }^{63}$ and South Africa ${ }^{64}$ In Malawi itself the larger hospitals in the South had used a 'Wellcome' test alone. ${ }^{12}$ However, smaller hospitals generally have had access only to the 'Serodia' particle agglutination test. We decided to evaluate all tests used in neighbouring countries, except for Abbott kits which use a bead technique requiring additional specialized equipment. All evaluated tests can be read either by eye (particle agglutination tests) or using a Multiskan (Flow Laboratories) 96-well platereader (ELISAs) purchased for the Chilumba laboratory.

2 A variety of antigen sources were considered. Many companies grow HIV for ELISAs and Western blots in $\mathrm{H} 9$ cells, but these cells may be a source of cross-reactions with African sera. ${ }^{42}$ In contrast, the virus used in ELAVIA kits is both an independent isolate (LAV) and is grown in the CEM cell line. For this reason, the Elavia ELISA was evaluated to provide an alternative antigen source to that used in Organon and Wellcome kits. Use of recombinant antigens may alleviate some of the problems of cultured virus. 
Table 2. Selected characteristics of the five serological tests evaluated.

\begin{tabular}{lccccc}
\hline & $\begin{array}{c}\text { Organon } \\
\text { Sandwich } \\
\text { ELISA }\end{array}$ & $\begin{array}{c}\text { Elavia } \\
\text { Sandwich } \\
\text { ELISA }\end{array}$ & $\begin{array}{c}\text { Wellcome } \\
\text { Competitive } \\
\text { ELISA }\end{array}$ & $\begin{array}{c}\text { Edgware } \\
\text { Particle } \\
\text { aggln. }\end{array}$ & $\begin{array}{c}\text { Serodia } \\
\text { Particle } \\
\text { aggln. }\end{array}$ \\
\hline Negative control per sample & no & yes & no & yes & yes \\
Recommended for plasma samples & yes & yes & (yes) & no & (no) \\
Recommended for heat-inactivated samples & no & no & yes & yes & yes \\
Recommended incubation temperature & $37^{\circ} \mathrm{C}$ & $37^{\circ} \mathrm{C}$ & $45^{\circ} \mathrm{C}$ & $\mathrm{RT}$ & $\mathrm{RT}$ \\
Test readable by eye & yes & no & yes & yes & yes \\
Printed record of results & yes & yes & yes & no & no \\
List price per test January 1990 & $£ 1.50$ & $£ 1.02$ & $£ 1.45$ & $£ 0.09$ & $£ 0.85$ \\
& & & & &
\end{tabular}

3 Tests employing several different techniques were to be included in the evaluation. Both indirect and competitive ELISAs were included, since these form a potentially useful combination of tests. ${ }^{39,51}$ Indirect ELISAs may be prone to false positives due to crossreactions,${ }^{39}$ but competitive ELISAs may be too specific to pick up newer variants of HIV in Africa ${ }^{30}$ Competitive ELISAs might be more likely to give false negatives, e.g. from washing problems,${ }^{51}$ but may be capable, like particle agglutination tests, of detecting IgM antibodies. ${ }^{50,51,65}$

4 Reported sensitivities (true positives/(true positives + false negatives)) and specificities (true negatives/(true negatives + false positives)) were considered from studies in which many different samples had been tested as well as from those in which end-point titrations had been assessed. ${ }^{35,36,43-45,47-49,54,66}$ Tests were usually reported to be both highly sensitive and highly specific (i.e. $>98 \%$ ) on European sera. It was noted that the reported sensitivity of particle agglutination tests was particularly high ${ }^{46,50,53,55,65,67,68}$ as was the sensitivity of tests incorporating recombinant antigens. ${ }^{69,70}$ However, there were relatively few evaluations carried out using sera from Africa, ${ }^{35-37,52,54,71}$ and hence we were hesitant to place too much emphasis on reported estimates of sensitivity and specificity.

5 Kits were evaluated if they had features likely to enhance specificity. ELAVIA kits, for example, incorporate an uncoated well for every antigen-coated well to serve as a blank for each sample. ${ }^{30}$ Organon kits require substantial $(1 / 34$ or $1 / 100)$ dilutions of sera prior to testing, thereby reducing interference by nonspecific factors. ${ }^{51}$ Problems with a peroxidase inhibitor, resulting in false positives, are known to occur with at least two of the three generations of Wellcome kits. ${ }^{51,54,66,72-75}$ This problem has not been reported for the Behring competitive ELISA. ${ }^{74}$

6 HIV-2 has not been reported from Malawi to date. However, to have an initial antiHIV-1 screening test which could also detect at least a proportion of HIV-2 positive sera. was considered important. No combined anti-HIV-1 and HIV-2 detection kits were available at the time of this evaluation, although in 1990 several kits are appearing on the market (e.g. Peptilav ${ }^{76}$ ). An indirect ELISA with whole HIV-1 viral antigen may detect up to $70 \%$ of HIV-2 positive individuals, whereas competitive ELISAs may pick up less than $50 \% .{ }^{54,70,77-79}$ Cross-reactivity between HIV-1 and HIV-2 is mainly associated with core proteins. ${ }^{77}$ Western blotting against both sets of viral antigens is necessary to differentiate between HIV-1 and HIV-2. Particle agglutination tests for detection of anti-HIV-1 are not suitable for the detection of anti-HIV-2. ${ }^{53,67}$ The efficiency with which sandwich ELISAs using recombinant HIV-1 antigens will detect anti-HIV-2 appears to depend on 
the nature of the antigens. ${ }^{69,70,79}$ The Organon sandwich ELISA included in our evaluation uses whole HIV-1 viral antigen and is reported to detect cross-reacting antibodies in more than $50 \%$ of HIV-2 infected individuals. ${ }^{77}$

7 Most of the blood samples to be used in the Malawi study are drawn by venepuncture. However, we wanted the option to use whole blood collected on filter paper. Some of the control specimens would be recalcified plasma. The Wellcome competitive ELISA has been used successfully to test sera dried on filter paper, ${ }^{80}$ and Litton Bionetics, ${ }^{81}$ ElectroNucleonics, ${ }^{81}$ Cellular Products ${ }^{82}$ and Organon Vironostika ${ }^{83}$ tests have been used successfully for testing dried whole blood on filter paper. The Wellcozyme recombinant ELISA gives false-negative results at the recommended incubation temperature of $45^{\circ} \mathrm{C}$ if plasma is used instead of serum. ${ }^{84}$ The Serodia particle agglutination test is also not recommended for use with plasma. We also considered reports of using heat inactivated sera $^{80,85}$ and filter paper dried bloodspots ${ }^{83}$ and whether any problems were found using haemolysed samples, or using stored or frozen-and-thawed sera. ${ }^{35,45,81,85,86}$

8 Choice of kit was also influenced by cost (e.g. see Table 2), reliability of supply, and the shelf life given for the kits at the time of supply. Supply problems were encountered only with Wellcome, which resulted in test evaluations being carried out on first-generation kits in London but on third-generation kits in Malawi. Shelf life was of particular interest for particle agglutination tests, where HIV-coated particles have only a limited lifespan after reconstitution.

Apart from these various practical considerations it was also important to bear in mind when carrying out our evaluation that the presence of high levels of antibodies and immune complexes associated with infectious diseases common in Africa, such as malaria, syphilis and leprosy, may reduce the specificity of HIV tests. ${ }^{42}$ In earlier studies, ${ }^{87-89}$ for example, prevalence of HIV was found to correlate with the magnitude of the anti- $P$. falciparum antibody response, even though no cross-reactivity between retroviruses and $P$. falciparum could be demonstrated ${ }^{87-90}$ False positives have also occurred with sera from leukaemic patients who have received multiple blood transfusions, ${ }^{46}$ and with sera containing anti-HLA antibodies, ${ }^{49,91-93}$ Drugs which are in common use in Africa must also be considered when HIV testing, since these may also interfere with antibody screening. Although these factors did not influence the choice of kits evaluated, they would need to be taken into account in interpreting results obtained.

After considering points 1 to 8 above, the kits (Table 2) we chose to evaluate for use in Malawi were: the sandwich ELISA tests Organon Vironostika anti-HTLVIII ( = 'Organon') and Diagnostics Pasteur ELAVIA Ac-Ab-Ak1 (='ELAVIA'); the competitive ELISA Wellcozyme anti-HTLVIII ( = 'Wellcome'); and the particle agglutination assays Fujirebio Serodia. HIV ( = 'Serodia'), and a rapid economical modification of the Serodia test developed ${ }^{67}$ at the North London Blood Transfusion Service (= 'Edgware').

\section{Evaluation of tests in London}

\section{FAMILIARIZATION WITH THE TESTS}

The first evaluation of these kits in London was performed on a small panel of welldefined samples: UK Public Health Laboratory Service (PHLS) positive, weak and low positive, and negative plasmas; and Malawian sera from known HIV positives and 
negatives, from an AIDS patient, from an HIV negative syphilitic, and from an HIV negative leprosy patient. This was primarily to familiarize ourselves with the kit protocols, and to test them under simulated field (e.g. varying incubation temperatures) conditions and with variable sample preparation (e.g. heat inactivation) methods.

All tests performed accurately according to their manufacturers' internal quality control criteria. In addition, when used strictly according to kit protocols, most tests gave the predicted results, even the Serodia test despite the fact that it is not recommended for use with plasma samples. Its Edgware modification did give false positives with plasmas at low dilution, and the Elavia kit gave readings between the negative and positive cut-off values (in what is classified as a 'negative but for repeat' category) for the weak and low positive control plasmas. Titrations using the known Malawian positive sera showed that the Serodia and Edgware particle agglutination assays were at least five times as sensitive as the Organon and Wellcome ELISAs. Hence, the Edgware test would provide a cheap and sensitive first screen test in a multitest screening protocol. Except for one nonrepeatable false positive by Edgware, no cross-reacting antibodies were detected by any test for the leprosy and syphilitic positive sera.

Heat inactivation $\left(3\right.$ hours, $56^{\circ} \mathrm{C}$ ) interfered with ELISAs but did not affect performance of the particle agglutination assays. The Wellcome ELISA failed to detect one low positive plasma when carried out at $37^{\circ} \mathrm{C}$ rather than the recommended $45^{\circ} \mathrm{C}$, although $37^{\circ} \mathrm{C}$ has been reported as a suitable incubation temperature for the recombinant kit when using plasma. ${ }^{84}$ The Edgware particle agglutination assay was found to work well at temperatures ranging from $4{ }^{\circ} \mathrm{C}$ to $37^{\circ} \mathrm{C}$ and thus would be robust under variable field conditions. It was necessary, however, to use particles freshly reconstituted or stored at $4^{\circ} \mathrm{C}$ for a maximum of two weeks. Particles stored in the freezer became sticky and frequently gave false positive results.

Plates from the Organon and Wellcome (but not Elavia because of the use of the uncoated blank well) ELISAs could be read by eye, which would be useful in the event of equipment failure. There is, however, little information concerning the sensitivity and specificity of visual readings,${ }^{94}$ and the results read by eye would not be quantitative. Similarly, results of the particle agglutination assays are read by eye and provide only $+/-$ data.

Following this initial screen, all test incubations were performed at $37^{\circ} \mathrm{C}$ and we decided not to heat inactivate any samples. The next step in our London evaluation was to test a larger panel of Malawian sera to establish that there were no additional problems with the assays specific to this population, and to see if we could establish a cheap and reliable multitest screening protocol for use in the Chilumba laboratory.

\section{TESTING MALAŴAN SAMPLES IN LONDON}

The second evaluation in London was carried out on 114 Malawian sera selected from a patient group we suspected would contain both HIV positive and HIV negative samples. These were screened initially using the Organon and Edgware tests. One hundred were negative by both methods. A sample of 34 of the 114 sera (including all Organon and Edgware positives) were tested by Wellcome, Serodia and Elavia methods. Of these 34 sera, six were positive by all five methods, and eight were positive by one or more but not all assays (Table 3 ). The remainder of the 34 were negative by all assays. Western blotting (Elavia HIV1 Blot and Biorad Blot) was performed on the eight variable result sera, but this did not completely resolve the problems which fell into three different categories: 
Table 3. Detailed results of eight sera which showed anomalous results.

\begin{tabular}{cccccccc}
\hline & Organon & Edgware & Wellcome & Serodia & Elavia & $\begin{array}{c}\text { Elavia blot } \\
(\text { HIV-1) }\end{array}$ & Biorad blot \\
\hline 3460 & -- & +- & - & + & - & - & - \\
3491 & -- & +- & - & + & - & - & $(-)$ \\
3495 & -- & +- & - & + & - & - & $(+)$ \\
3511 & -- & -- & - & - & ++ & $(-)$ & $(-)$ \\
3516 & -- & -- & - & - & $(+)+$ & $(-)$ & $(-)$ \\
3528 & -- & -- & - & - & $(+)+$ & - & $(+)$ \\
3440 & -- & -+ & ++ & - & -- & - & $(-)$ \\
3509 & -- & $(-)+$ & $(-)-$ & + & $-(+)$ & & \\
\hline
\end{tabular}

( ) ELISA (Wellcome and Elavia) = results within $10 \%$ of cut off.

( ) Particle agglutination tests $=$ doubtful result (see text) (Edgware and Serodia).

$(+)$ Western blotting $=$ weak anti-core and anti-envelope activity.

(-) Western blotting = indeterminate (i.e. anti-core or anti-envelope only).

Two results indicate that the samples were tested twice.

1 Three sera were clearly positive by particle agglutination tests but negative by ELISA and Western blotting (see Table 3). Since Western blotting may not be the most sensitive technique, ${ }^{32,33,50}$ a negative Western blot result does not rule out a positive HIV response. Repeat sampling, which is exceedingly difficult in the project area, would be required to determine whether these were false positives or seroconverters.

2 Some problems were specific to the Elavia ELISA test kit. This is demonstrated by examination of the distribution of test OD/cut off OD values for the ELISA tests (Figure 1), which indicates the segregation of positive and negative values. ${ }^{47}$ The clearest separation of positive and negative values was given by the Organon kit. Three samples were over the cut off by the Elavia test (Figure 1) but failed to react by other tests (Table $3)$. Indeterminate results were obtained when these 3 sera were incubated with Elavia HIVl blot strips (Table 3) and, when blotted against Elavia HIV2 Western blot strips (not shown), they showed reactivity only against core proteins - an inconclusive result. These results were reminiscent of the problems we had encountered earlier with weak and low positive control plasmas, and we decided not to include Elavia kits in further development of the routine screening protocol.

3 One sample (3440, Table 3), which was positive only by Wellcome ELISA, was HIV negative when the Wellcome test was performed as a sequential ELISA adding serum prior to the addition of conjugate. This was consistent with previous observations ${ }^{66,72-74}$ of false positives due to the presence of a peroxidase inhibitor in the serum.

\section{Establishment of an HIV multitest protocol}

On the basis of these two evaluations, the following multitest protocol for HIV testing was developed for use in the Chilumba laboratory:

1 All samples to be screened initially by two tests based on different principles - the 

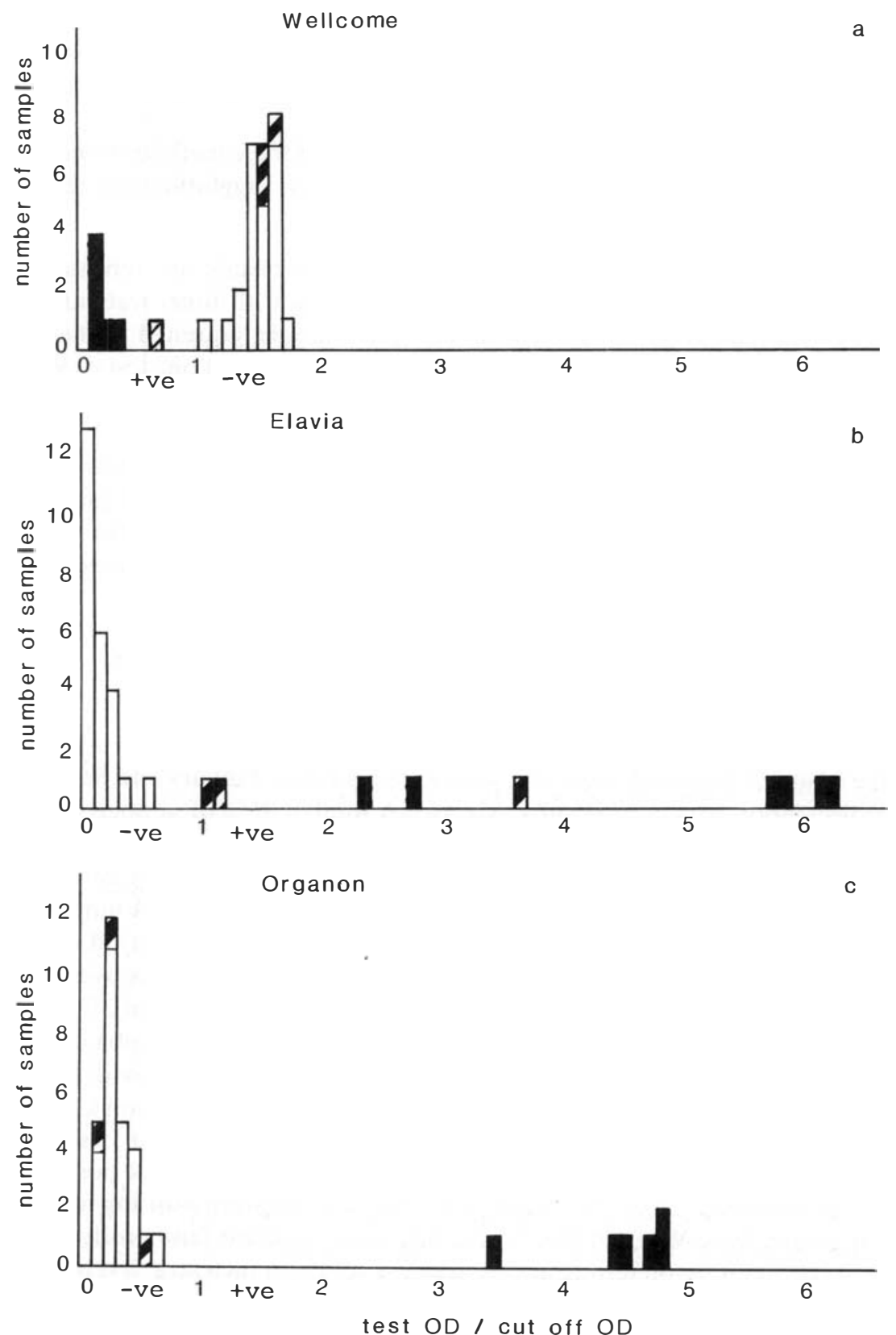

Figure 1. Ratio of test OD values to kit cut off OD values for 34 samples and 3 ELISAs. Wellcome competitive ELISA (a): HIV negative $=$ test $\mathrm{OD} /$ cut off OD $>1$. HIV positive $=$ test $\mathrm{OD} /$ cut off $\mathrm{OD}<1$. Elavia sandwich (b) and Organon sandwich (c) ELISAs: HIV negative $=$ test $\mathrm{OD} /$ cut off $\mathrm{OD}<1$. HIV positive $=$ test $\mathrm{OD} /$ cut off $\mathrm{OD}>1$. Key Wellcome Elavia Organon Edgware Serodia

$\begin{array}{llllll}\square & - & - & - & - & - \\ \square & + & - & - & - & - \\ \square & - & + & - & - & - \\ \square & + & + & + & + & +\end{array}$


Organon sandwich ELISA (which may also detect cross reacting antibodies to HIV2) and the Edgware particle agglutination test (which is the cheapest test available, quick to perform and very sensitive). Samples negative by both Organon and Edgware methods to be scored HIV negative.

2 Confirmation of positives detected by either or both of these methods to be carried out by Wellcome competitive ELISA and Serodia particle agglutination test. Samples reacting by all 4 methods to be scored HIV positive.

Where practical, tests on samples showing anomalous results are repeated. Samples positive (preferably repeatedly) by one or more (but not all four) tests are examined further in London by Western blotting, and a repeat sample requested. If the HIV status remains indeterminate, i.e. with anomalous results on more than one test or where either of the ELISA results clearly differed from the results of the other 3 tests, these cases are assigned to an indeterminate category for epidemiological analysis.

The major equipment purchased for the Chilumba laboratory to implement the above protocol comprised a Damon IEC Centra4B centrifuge, together with plate carriers, a Flow Multiskan plus MkII platereader, a Flow Handiwash plate washer together with pump, and a selection of Labsystems Finnpipettes. The total cost of this equipment was approximately $£ 9000$.

\section{HIV testing in Malaŵi}

Using the multitest protocol, 1455 sera were tested between January and September 1989 at the project laboratory in Chilumba, Malawi. A total of $95 \%$ of samples screened gave unequivocal results on initial testing: $14 \%$ positive and $81 \%$ negative. The remaining $5 \%$ of samples required repeat or additional tests. A major problem in the early testing was due to samples which gave values over the cut off in the Organon ELISA but were negative by other tests. These sera gave OD values between 1 and 2 times the cut-off values, falling between negative (test $\mathrm{OD} /$ cut off $\mathrm{OD}<1$ ) and multitest confirmed positives in which the test $\mathrm{OD} /$ cut off $\mathrm{OD}$ ratios ranged, for the first 100 samples tested, from $2 \cdot 3$ to 16 (Figure 2). In the majority of cases a second Organon testing (either at Chilumba or in London) gave a negative result, but the occasional sample showed a persistent weak reaction. This problem was at least in part associated with batch variation in Organon kits, a problem also reported by others. ${ }^{47}$ Western blotting (Biorad Blot) in London of 15 samples which had shown weak positive reactions by Organon revealed 4 with weak positive Western blot profiles. However, since the Organon ELISA and Western blotting are based on a similar principle, these Western blot results may also represent false positive reactions. ${ }^{23}$ Since most repeat Organon testing gave a negative result on such sera, it is highly unlikely that these samples are true positives. This problem may only be resolved by longitudinal repeat testing of the individuals concerned.

During 1989, 22 samples gave positive reactions with one or both of the particle agglutination tests, but were negative by ELISA. This was similar to the pattern of reaction we had observed for some sera in the first screen of Malawian samples in London, and has been reported by others. ${ }^{50,52}$ Western blotting of 18 of these revealed only 2 positives. Repeat venepuncture specimens were acquired from 5 individuals which proved negative by repeat particle agglutination testing. Sensitivity and specificity values 


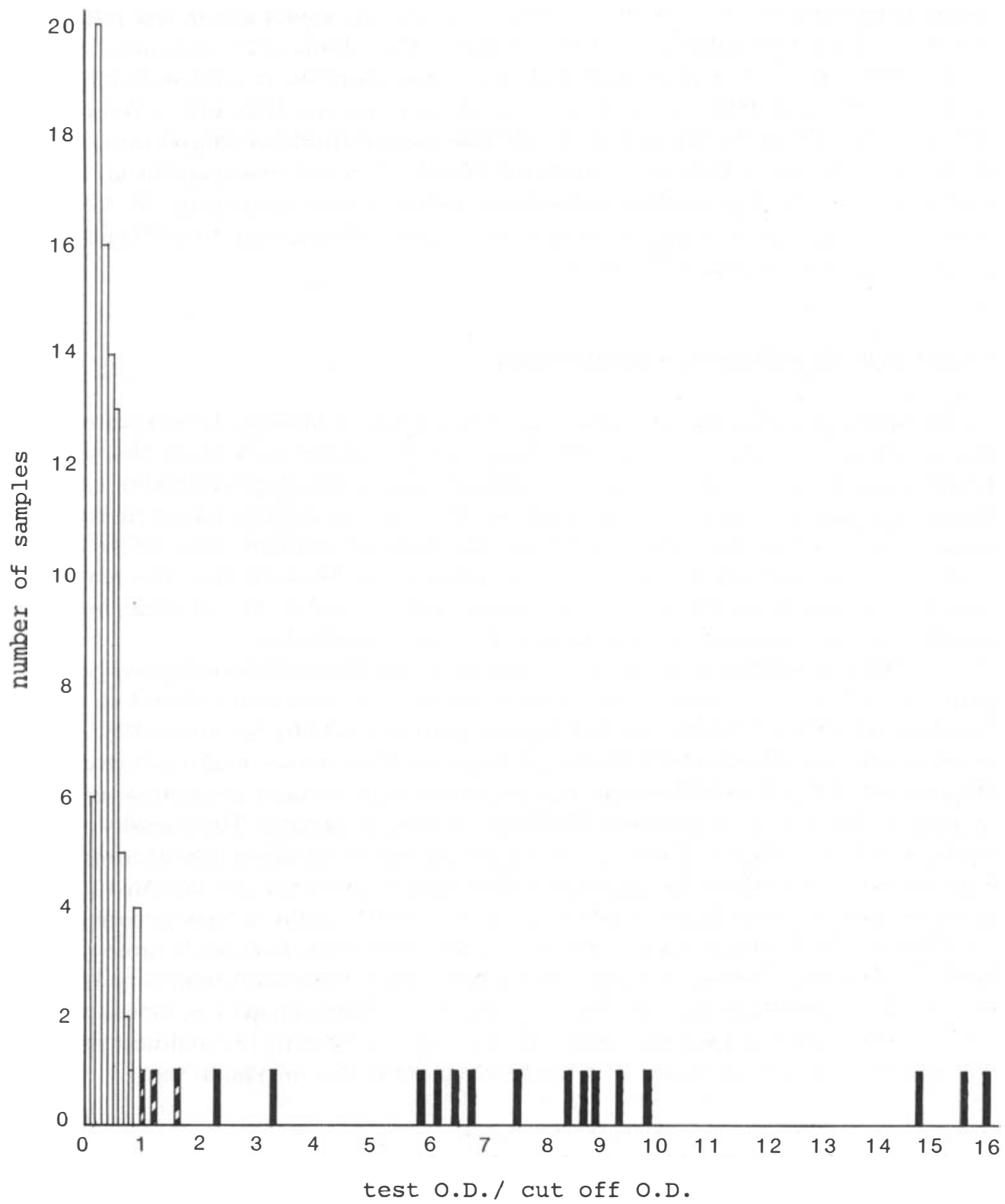

Figure 2. Ratio of test $O D$ values to kit cut off $O D$ values for the first 100 samples tested in Malawi by Organon ELISA. $\square$ negative; low positive; $\square$ positive.

cannot be calculated for this series of tests since not all tests were performed on all samples. However, the possibility that particle agglutination tests show low specificity cannot be proved without extensive resampling of patients, since the sensitivity of these techniques is particularly high. Occasionally both control unsensitized particles and sensitized particles reacted with the sample. We did not absorb these sera with 
unsensitized particles prior to repeat testing, but particle agglutination test results for such sera were not included when determining the HIV status of the individual.

The Wellcome ELISA performed well as a confirmatory test in our hands. However, supply problems required that we change from Wellcozyme anti-HTLVIII to Wellcozyme HIV recombinant, and at the end of March 1989 supply problems obliged us to replace Wellcome tests with a Behring competitive ELISA. This test was used for all further studies. Due to the high ambient temperature in the Malawi laboratory $\left(28-36^{\circ} \mathrm{C}\right)$ the time for development of colour in the Behring test was reduced from 30 to 20 minutes to fulfill quality control criteria for the kits.

\section{Validation of the multitest screening protocol}

As one means of validating the multitest protocol set up in Malawi, 32 sera scored HIV positive by all tests and 52 scored HIV negative were applied to Western blot strips in London. Of the 32 positives, 30 had both anticore and antienvelope antibodies, i.e. were positive by standard criteria. ${ }^{13,14}$ One of the two Western blot negatives was a tuberculosis patient who may have had clinical AIDS and thus reduced antibody titres. Of the 52 sera negative by the multitest protocol, 51 were 'negative' by Western blot. The remaining sample could not be scored due to high background. A total of $20 \%$ of these 'negative' samples showed significant levels of anti-p24 anti-core antibodies.

It was also important to establish that sera from syphilitics and from leprosy patients, particularly those from lepromatous patients, did not cross react in any of the tests to give false positive results. ${ }^{95}$ Of 184 sera from leprosy patients tested by September 1989, only 4 were not clearly resolved as HIV positive or negative. These 4 were weakly positive by the Organon ELISA and their frequency was no greater than amongst nonleprosy sera. One of these samples was also reactive by Wellcome and one by Serodia. The majority of these leprosy cases are tuberculoid and therefore have low leprosy specific antibody titres. ${ }^{96}$ The requirement that samples be reactive by four tests before they are accepted as HIV positive should provide accurate information on the HIV status of leprosy patients.

Of 60 syphilis positive sera tested by September 1989, three had one or more positive agglutination results but were negative by ELISA. One of these was found to be Western blot positive (described above). This frequency of problem samples is similar to that occurring amongst total samples tested. Hence, our results using the multitest protocol are unlikely to be compromised by cross-reacting antibodies in syphilis sera.

\section{Quality control and further kit evaluation in Malaŵi}

Routine quality control procedures were established in the Chilumba laboratory using a panel of high/weak/low/extra low positive and negative plasmas, and a quality control panel, obtained from the Public Health Laboratory Service at Colindale. These samples were transported to Malawi freeze-dried, reconstituted, aliquotted and stored frozen $\left(-20^{\circ} \mathrm{C}\right)$ for future testing. Since we had noted batch variation in Organon test kits, it was stipulated that these samples should be tested by all methods on arrival of new Organon kits in Malawi (approximately every 3 months). Once the initial screening was underway in Malawii, a pool of Malawiian positive sera was made for inclusion in the quality control 
test panel. This pool was titrated both in London and in Malawi, with endpoint titres in good agreement.

To ensure that any problems can be tracked down at the time of data analysis, the date, technician identity, laboratory temperature and, for Organon, the kit batch number, are recorded for each individual test. All printouts of ELISA results are stored and all patterns on particle agglutination plates drawn by the technicians.

In view of the batch problem with Organon kits, the Du Pont HIV ELISA and the second generation Du Pont HIV-1 recombinant ELISA have since been evaluated alongside the routine four test regime as possible alternative sandwich ELISAs. In Malawi, 210 and 241 samples, which had produced clear positive or negative results by the four test protocol, were tested by the two Du Pont ELISAs respectively. The Du Pont HIV ELISA had a sensitivity of $78 \%$ and a specificity of $73 \%$, and the Du Pont HIV-1 recombinant ELISA had a sensitivity of $82 \%$ and a specificity of $62 \%$, when compared to the established testing regime. These values are not comparable with reported sensitivity and specificity values since the Western blot has not been used as a 'gold standard' (see below). In addition, the recombinant kit tested in Malawi failed to show the sensitivity observed in London on titration of the known positive pool. Thus, in our hands, these tests did not perform in Malawi to the same standard as other tests and have not been considered for inclusion in our multitest protocol.

\section{Conclusion}

Different protocols for establishing HIV status will be appropriate in different contexts. A hospital diagnostic laboratory or blood bank may have requirements which differ from those of a research project. Kit selection will inevitably be based upon many considerations, such as cost, availability of equipment, and staff expertise, in addition to the performance of the test. Test performance will itself be a function of other variables, such as the quality of samples collected, the presence of HIV-2 in the population, and the presence of other infections or drugs which may affect test specificity.

It is important to evaluate the sensitivity and the specificity of whatever tests are to be utilized, in the actual context in which they are to be used. These parameters will be dependent at least to some degree upon the conditions in which the tests are applied. Thus the values cited in this paper, reflecting the performance of tests in our hands, need not obtain universally. It is also important to recognize that the ultimate predictive value of a test protocol-defined as the proportion of test positives which represent true HIV infections - will be a function not only of test sensitivity and specificity, but also of the prevalence of HIV infection in the population. Thus the proportion of false positive results will be inversely related to the prevalence of HIV infection-and should therefore decline as the prevalence of HIV in the community increases. Algebraic formulations of the relationship between predictive value and test sensitivity, test specificity and infection prevalence, are found in several publications (e.g. Burgess et al. ${ }^{96}$ ).

Given that the motive of our work in Malawi is primarily to investigate whether there is an association between HIV infection and clinical leprosy, it was important that our HIV testing protocol have high sensitivity, in order that we may be confident of recognizing the presence of HIV in the study population. Of equal importance, however, 
was the requirement for high specificity, as the presence of false positive results would bias the observed relative risks towards unity.

On the basis of the investigations discussed in this paper, we ultimately decided upon a two-stage protocol incorporating four tests: an initial screen involving a sandwich ELISA together with a cheap modified particle agglutination test, followed by confirmatory testing with a competitive ELISA and a particle agglutination test. The order was determined by the requirement that the initial screen in the protocol have extremely high sensitivity (in order to minimize false negatives), and that the confirmatory assays have high specificity (in order to minimize false positives). Even such a battery of tests turns out to be cheaper and easier than the employment of Western blots.

Initial evaluation of several tests, and using more than one test at screening and confirmation stages, has highlighted problems associated with individual tests. The Western blot has, in this instance, been used only as an alternative test to shed light on problems but not as a 'gold standard'. We thus have refrained from calculating estimates of sensitivity and specificity. Effort has been made to validate the above procedure, with respect to more widely used testing regimens and with respect to particular diseases endemic in Malawî, and also to establish quality control routines.

As kits detecting anti-HIV antibodies are further developed, it is likely that recombinant antigens will largely replace use of whole virus. Such kits require extensive evaluation to confirm that their apparent high sensitivity on Western samples is similar for samples of other origins and that their high specificity still allows detection of antibodies to all strains of HIV.

\section{Acknowledgments}

This work was supported primarily by the British Leprosy Relief Association (LEPRA). Additional support from the IMMLEP (Immunology of Leprosy) component of the WHO/UNDP/World Bank Special Programme for Research and Training in Tropical Diseases and from the Who Global Programme on AIDS is also gratefully acknowledged.

\section{References}

1 Nunn PP, McAdam KPWJ. Mycobacterial infections and AIDS. Brit Med Bull, 1988; 44: 3, 801-13.

2 Mets T, Ngendahayo P, Van de Perre P, Mutwewingabo A. HIV infection and tuberculosis in Central Africa. $N$ Engl J Med, 1989; 321: 542-3.

3 Lamfers EJP, Bastiaans AH, Mravunac M, Rampen FHJ. Leprosy in the Aquired Immune Deficiency Syndrome. Ann Int Med, 1987; 107: 111-12.

${ }^{4}$ Meeran K. Prevalence of HIV infection among patients with leprosy and tuberculosis in rural $\mathrm{Zambia} . \mathrm{Br}$ Med J, 1989; 298: 364-5.

5 Turk JL, Rees RJW. AIDS and leprosy. Lepr Rev, 1988; 59: 193-4.

${ }^{6}$ Fine PEM, Ponnighaus JM. Leprosy in Malawi 2. Background, design and prospects of the Karonga Prevention Trial, a leprosy vaccine trial in Northern Malawi. Trans Roy Soc Trop Med Hyg, 1988; 82: 810-17.

7 Cheesbrough JS. Aquired Immune Deficiency Syndrome in Malawi. J Med Assoc Malawii, 1986; 3: 5-13.

${ }^{8}$ Sher R. Seroepidemiological studies of HTLVIII/LAV inf ections in southern Af rican countries. International Symposium on African AIDS, 1985; Abstract 06/I.

9 Cheesbrough JS, Liomba NG, Sutorius FFJM, Molyneux ME. Histiocytic medullary reticulosis associated with positive human immunodeficiency virus 1 (HIV1) serology in two African patients. Trans Roy Soc Trop Med Hyg, 1989; 83: 259.

10 Chiphangwi J, Liomba G, Ntaba HM, Schmidt H, Deinhardt F, Eberle J, Frosner G, Gurtler L, Zoulek G. Human Immunodeficiency Virus is prevalent in Malawi. Infection, 1987; 59: 363.

11 Gompertz S, Harrison C. HIV infection in Malawi. Br Med J, 1989; 299: 56.

12 Reeve PA. HIV infection in patients admitted to a general hospital in Malawi. Br Med J, 1989; 298: $1567-8$. 
13 Centers for Disease Control. Interpretation and use of the western blot assay for serodiagnosis of human immunodeficiency type 1 infections. $M M W R, 1989 ; 38:$ S7.

14 Consortium for Retrovirus Serology. Serological diagnosis of human immunodeficiency virus infection by western blot testing. JAMA, 1988; 260: 674-9.

15 Burke DS, Redfield RR, Putman P, Alexander SS. Variations in western blot banding patterns of human Tcell lymphotropic virus type III/lymphadenopathy-associated virus. J Clin Micro, 1987; 25: 81-4.

16 Re MC, Furlini G, Baldassarri B, Chiodo F. Serological study of subjects with seroconversion to human immunodeficiency virus. Eur J Clin Micro Infect Dis, 1988; 7: 144-8.

17 Lange JMA, Coutinho RA, Krone WJA, Verdonck LF, Danner SA, Van der Nordaa J, Goupsmit J. Distinct IgG recognition patterns during progression of subclinical and clinical infection with lymphadenopathy associated/human T lymphotropic virus. Br Med J, 1986; 292: 228-30.

18 Hosburgh CR, Ou CY, Jason J, Holmberg SD, Longini IM, Schable C, Mayer KH, Lifson AR, Schochetman G, Ward JW, Rutherford GW, Evatt BL, Seage GR, Jaffe HW. Human immunodeficiency virus infection bef ore detection of antibody. Lancet, 1989; ii: 637-9.

19 Van den Akker, Bouman-Van Engelen CAA, De Jong JC, Dolmans WMV, Van Loon AM, Mulder DW, Shao JF. Persistance of anti-HIV p24 antibodies in African AIDS patients. AIDS, 1988; 2: 62-3.

20 Lefrere JJ, Courouce AM, Lucotte G, Boitard C, Kaplan C, Nicolas JC, Bricout F, Lambin P, Doinel C, Muller JY, Bach JF, Salmon C. Follow up of subjects with isolated and persistent anti-core (anti-p24 or antip17) antibodies to HIV. AIDS, 1988; 2: 287-90.

21 Van der Poel CL, Reesink HW, Tersmette TH, Lelie PN, Huisman H, Meidema F. Blood donations reactive for HIV in western blot but non-infective in culture and recipients of blood. Lancet, 1986; ii: 752-3.

22 Courouce AM, Muller JY, Richard D. False positive western blot reactions to human immunodeficiency virus in blood donors. Lancet, 1986; ii: 921-2.

23 Biberfield G, Bredberg-Raden U, Bottiger B, Putkonen P, Blomberg J, Juto P, Wadell G. Blood donor sera with false positive western blot reactions to human immunodeficiency virus. Lancet 1986; ii: 289-90.

${ }^{24}$ Saag MS, Britz J. Asymptomatic blood donor with a false positive HTLV-III Western blot. $N$ Engl J Med, 1986; 314: 118

25 Moore JD, Cone EJ, Alexander S. HTLV-III seropositivity in 1971-1972 parenteral drug abusers-a case of false positives or evidence of viral exposure? $N$ Engl J Med, 1986; 314: 1387-8.

26 Anonymous. 'Indeterminate' Western blots and HIV. Lancet, 1989; ii: 516.

27 Ganesca J, Wai-Kuo Shih J, Jett BW, Hewlett IK, Epstein JS, Alter HJ. What do Western blot indeterminate patterns for human immunodeficiency virus mean in EIA-negative blood donors? Lancet, 1989; ii: 1023-5.

28 Bukrinsky MI, Chadlinskas SA, Syrtsev VA, Bravkilene LA, Philippov YV. Reactivity to gag- and envrelated proteins in immunoblot assay is not necessarily indicative of HIV infection. AIDS, 1988; 2: 405-6.

${ }^{29}$ Courouce AM. Following up indeterminate HIV-1 Western blots. Lancet, 1989; ii: 1330-1.

30 Tedder R. Which AIDS test for Africa? Africa Health, Feb/Mar 1987; 10-11.

${ }^{31}$ Leitman SF, Klein HG, Melpolder JJ, Read EJ, Esteban JI, Leonard EM, Harvath L, Shih JW, Nealon R, Foy J, Darr F, Alter HJ. Clinical implications of positive tests for antibodies to human immunodeficiency virus typel in asymptomatic blood donors. $N$ Engl J Med, 1989; 321: 917-24.

32 Oldham LG, Moulsdale HJ, Mortimer PP, Tedder RS, Morgan-Capner P. How sensitive are the commercial assays for anti-HTLVIII/LAV? J Med Virol, 1987; 21: 75-9.

33 Toswill JHC, Parry JV, Mortimer PP. Sensitivity of the newer HIV assays. AIDS, 1988; 2: 230.

${ }^{34}$ Day A, Mortimer PP. Simplified confirmatory HIV testing. Lancet, 1988; ii: 509-10.

35 Van de Perre P, Nzaramba D, Allen S, Riggin CH, Sprecher Goldberger S, Butzler JP. Comparison of six serological assays for human immunodeficiency virus antibody detection in developing countries. $J$ Clin Micro, 1988; 26: 552-6.

36 Vercauteren G, Van der Groen G, Piot P. Comparison of enzyme immunoassays and an immunofluorescence test for detection of antibody to human immunodeficiency virus in African sera. Eur J Clin Micro, 1987; 6: 132-5.

37 Constantine NT, Fox E, Abbatte EA, Woody JN. Diagnostic usefulness of five screening assaysf or HIV in an East African city where prevalence of infection is low. AIDS, 1989; 3: 313-17.

38 Fleming AF. Simplified confirmatory HIV testing. Lancet, 1988; ii: 848.

39 Tedder R. Which AIDS test?-a further rejoinder. Africa Health, Dec 1987/Jan 1988; 8-9.

40 Biggar RJ. The AIDS problem in Africa. Lancet, 1986; i: 79-82.

${ }^{41}$ Hunsmann G, Schneider J, Wendler I, Fleming AF. HTLV positivity in Africans. Lancet, 1985 ; ii: 952.

42 Anonymous. AIDS in Africa. AIDS-Forschung, Jan 1987; 5-25.

43 Mortimer PP, Moulsdale HJ, Oldham LJ, Parry JV, Pereira MS, Mortimer JY, Kennedy DA, Lister PA. PHLS and DHSS evaluation of ten commercial anti HTLVIII/LAV assay kits. 1986.

44 Bayliss GJ, Taylor H, Mortimer PP, Parry JV, Kennedy DA, Lister PA. PHLS and DHSS evaluation of four commercial anti-HIV kits. 1987.

45 Courouce AM. Evaluation of eight ELISA kits for the detection of anti-LAV/HTLVIII antibodies. Lancet, 1986; ii: $1152-3$.

46 Ohya K, Morishima Y, Funato E, Hasegawa I, Kamiya T. Screening blood donors for antibody to human immunodeficiency virus typel by sensitive particle agglutination assay. Vox Sang, 1988; 55: 148-51. 
47 Ozanne G, Fauvel M. Performance and reliability of five commercial enzyme-linked immunosorbent assay kits in screening for anti human immunodeficiency virus antibody in high risk subjects. J Clin Micro, 1988; 26: $1496-1500$

48 Deinhardt F, Eberle J, Gurtler L. Sensitivity and specificity of eight commercial and one recombinant anti HIV ELISA tests. Lancet, 1987; i: 40.

49 Reesink HW, Lelie PN, Huisman JG, Schaasberg W, Gonsalves M, Aaij C, Winkel IN, Van der Does JA, Hekker AC, Desmyter J, Goudsmit J. Evaluation of six enzyme immunoassays for antibody against human immunodeficiency virus. Lancet, 1986; ii: 483-6.

50 Healey DS, Maskill WJ, Gust ID. Detection of anti-HIV immunoglobulin $\mathbf{M}$ by particle agglutination following acute HIV infection. AIDS, 1989; 3: 301-4.

51 Ocheng D. Which AIDS test for Africa-a rejoinder. Africa Health, Aug/Sept 1987; $10-11$

52 Francis HL, Kabeya M, Kafuama M, Riggins C, Colebunders R, Ryder R, Curran J, Izaley L, Quinn TC. Comparison of sensitivities and specificities of latex agglutination and an enzyme-linked immunosorbant assay for detection of antibodies to the human immunodeficiency virus in Af rican sera. J Clin Micro, 1988; 26: $2462-4$

53 Quinn TC, Riggin CH, Kline RL, Francis H, Mulanga K, Sension MG, Fauci AS. Rapid latex agglutination assay using recombinant envelope polypeptide for the detection of antibody to the HIV. JAMA, 1988; 260: 510-13.

54 Bredberg-Raden U, Kiango J, Mhula F, Biberfeld G. Evaluation of commercial enzyme immunoassays for anti-HIV1 using east African sera. AIDS, 1988; 2: 281-5.

55 Mathiot CC, Georges-Courbot MC, Georges AJ. Evaluation of 12 kits for HIV antibody detection with a reference panel of African sera. Ann Inst Past/Virol, 1988; 139: 243-7.

56 Mhalu F, Bredberg-Raden U, Mbena E, Pallangyo K, Kiango J, Mbise R, Nyamuryekunge K, Biberfeld G. Prevalence of HIV infection in healthy subjects and groups of patients in Tanzania. AIDS, 1987; 1:217-21.

57 Van der Perre P, Le P olain B, Carael M, Nzaramba D, Zissis G, Butzler JP. HIV antibodies in a remote rural area in Rwanda, Central Africa: an analysis of potential risk factors for HIV seropositivity. AIDS, 1987; 1: 213-15.

58 Van der Perre P, Carael M, Nzaramba D, Zissis G, Kayihigi J, Butzler JP. Risk factors for HIV seropositivity in selected urban-based Rwandese adults. AIDS, 1987; 1: 207-11.

59 Rwandese HIV Seroprevalence Study Group. Nationwide community-based serological survey of H IV 1 and other human retrovirus infections in a central African country. Lancet, 1989; i: 941-3.

60 Simooya OO, Mwendapole R, Siziya S, Fleming AF. Relation between falciparum malaria and HIV seropositivity in Ndola, Zambia. Br Med J, 1988; 297: 30-1.

${ }^{61}$ Carswell JW. HIV infection in healthy persons in Uganda. AIDS, 1987; 1: 223-7.

${ }^{62}$ Hudson CP, Hennis AJM, Kataaha P, Lloyd G, Moore T, Sutehall GM, Whetstone R, Wreghitt T, Karpas A. Risk factors for the spread of AIDS in rural Africa: evidence from a comparative seroepidemiological survey of AIDS, hepatitis B and syphilis in southwestern Uganda. AIDS, 1988; 2: 255-60.

${ }^{63}$ Emmanuel JC, Smith HJ, Paterson LE. Western blot testing among Zimbabwean HIV patients. Vox Sang, 1988; 55: 247-8

${ }^{64}$ Dusheiko GM, Brink BA, Conradie JD, Marimuthu T, Sher R. Regional prevalence of hepatitis B, delta and human immunodeficiency virus infection in Southern Africa: a large population survey. Am J Epid, 1989; 129: $138-45$.

${ }^{65}$ Muller F, Gromm M, Muller KH. Partikel-agglutinationstest: eine neue Technik zum Nachweis von HIV1Antikorpern. Immun Infekt, 1988; 16: 148-51.

${ }^{66}$ Challis P, Dow BC, Mitchell R, Barr A, Barbara JAJ. Sequential ELISA for anti-HIV should not replace the standard competitive method. Vox Sang, 1988; 55: 244-5.

67 Barbara JA J, Salker R, Challis P, Contreras M. Gelatin particle agglutination assay for HIV antibodies: a rapid, economical modification with increased sensitivity. Med Lab Sci, 1989; 46: 135-40.

68 Sng EH, Tan BB, Chik HL. Comparative evaluation of particle agglutination test for antibody to human immunodeficiency virus. Genitourin Med, 1988; 64: 266-9.

${ }^{69}$ Narvanen A, Korkolainen M, Suni J, Korpela J, Kontio S, Partanen P, Vaheri A, Huhtala ML. Synthetic env gp4l peptide as a sensitive and specific diagnostic reagent in different stages of human immunodeficiency virus typel infection. J Med Virol, 1988; 26: 111-18.

${ }^{70}$ Lelie PN, Van der Poel CL, Reesink HW, Huisman HG, Boucher CAB, Goudsmit J. Efficacy of the latest generation of antibody assays for (early) detection of HIV 1 and HIV2 infection. Vox Sang, 1989; 56: 59-61.

71 Pachciarz J, Barnes A. Rapid screening tests for HIV. Jama, 1989; 261: 1147-8.

72 Roberts CA, Berrisford CH, Duncan RJS. False positive anti-HIV tests with Wellcome kits. Lancet, 1988; i: 996-7.

73 Mitchell R, Dow BC, Barr A, Follet EAC. False positive anti-HIV tests on blood donations. Lancet, 1988; i: 297-8.

74 Thorstensson R, Helgesson M, Putkonen P, Biberfeld G. False-positive reactions by Wellcozyme anti-HIV ELISA. AIDS, 1988; 2: 320-1.

75 Barr A, Muir W, Dow BC, Arnott J, Macvarish IP. Detection of anti-HTLVIII: modification of a commercial enzyme immunoassay. Med Lab Sci, 1987; 44: 97-9. 
76 Caruso BMT, Dorizzi RM, Tagliaro F, Giavarina M, Ferro A, Dusi S, Biasioli B, Tridente G. Rapid discrimination between HIV-1 and HIV-2 infection. Lancet, 1989; ii: 1156-7.

77 Denis F, Leonard G, Sangare F, Gershy-Damet G, Rey JL, Soro B, Schmidt D, Mounier M, Verdier M, Baillou A, Barin F. Comparison of 10 enzyme immunoassays for detection of antibody to human immunodeficiency virus type 2 in West African sera. J Clin Micro, 1988; 26: 1000-4.

78 Denis F, Leonard G, Mounier M, Sangare A, Gershy-Damet G, Rey JL, Barin F. Efficacy of five enzyme immunoassays for antibody to HIV in detecting antibody to HTLVIV. Lancet, 1987; i: 324-5.

79 Peeters M, Delaporte E, Dazza MC, Brun-Vezinet F. Detection of HIV-2 antibodies using five commercial HIV enzyme immunoassays. AIDS, 1988; 2: 389-90.

80 Das PC, El Hamy SM, El Berry S, Devries AH, McShine RL, Smit Sibinga CTH. HIV antibody on paperdried sera. Lancet, 1988; ii: 221-2.

81 Farzadegan H, Quinn T, Polk BF. Detecting antibodies to human immunodeficiency virus in dried blood on filter papers. $J$ Infec Dis, 1987; 155: 1073-4.

82 Varnier OE, Lillo FB, Reina S., De Maria A, Terragna A, Schito G. Whole blood collection on filter paper is an effective means of obtaining samples for human immunodeficiency virus antibody assay. AIDS Res and Hum. Retro, 1988; 4: 131-6.

${ }^{83}$ Evengard B, Von Sydow M, Ehrnst A, Pehrson PO, Lundbergh P, Linder E. Filter paper sampling of blood infected with HIV: effect of heat on antibody activity and viral infectivity. Br Med J, 1988; $297: 1178$.

${ }^{84}$ Loveday C, Tedder R. Effects of temperature on reactivity of plasma in recombinant HIV-1 competitive assay. Lancet, 1989; i: 723.

${ }^{85}$ McBride JH, Howanitz PJ, Rodgerson DO, Miles J, Peter JB. Influence of specimen treatment on nonreactive HTLVIII sera. AIDS Res and Hum Retro, 1987; 3: 333-9.

${ }^{86}$ Fipps DR, Damato JJ, Brandt B, Burke DS. Effects of multiple freeze thaws and various temperatures on the reactivity of human immunodeficiency virus antibody using three detection assays. $J$ Virol Methods, 1988; 20: 127-32.

87 Biggar RJ, Gigase PL, Melbye M, Kestens L, Sarin PS, Bodner AJ, Demedts P, Stevens WJ, Paluku L, Delacollette C, Blattner WA. ELISA HTLVIII retrovirus antibody reactivity associated with malaria and immune complexes in healthy Africans. Lancet, 1985; ii: 520-3.

88 Biggar RJ, Johnson BK, Oster C, Sarin PS, Ocheng D, Tukei P, Nsanze H, Alexander S, Bodner AJ, Siongok T, Gallo RC, Blattner WA. Regional variation in prevalence of antibody against human T-lymphotropic virus types I and III in Kenya, East Africa. Int J Can, 1985; 35: 763-7.

89 Biggar RJ, Melbye M, Kestens L, De Feyter M, Saxinger C, Bodner AJ, Paluko L, Blattner WA, Gigase PL. Seroepidemiology of HTLVIII antibodies in a remote population of eastern Zaire. Br MedJ, 1985; 290: 80810.

90 Schupbach J, Tanner M. Specificity of human immunodeficiency virus (LA V/HTLVIII)-reactive antibodies in African sera from southeastern Tanzania. Acta Trop, 1986; 43: 195-206.

91 Kuhnl P, Seidl S, Holzberger G. HLA DR4 antibodies cause positive HTLVIII antibody ELISA results. Lancet, 1985; i: 1222-3.

92 Weiss SH, Mann DL, Murray C, Popovic M. HLA-DR antibodies and HTLVIII antibody ELISA testing. Lancet, 1985; ii: 157.

93 Hunter JB, Menitove JE. HLA antibodies detected by ELISA HTLVIII antibody kits. Lancet, 1985; ii: 397.

${ }^{94}$ Mann JM, Francis H, Mwandagalirwa K, Ndongala L, Mavunza-Paka D, Baekert G, Malonga M, Bosenge N, Nzilambi N, Colebunders RC, Piot P, Quinn TC, Curran JW. ELISA readers and HIV antibody testing in developing countries. Lancet, 1986; i: 1505 .

95 Nuti M, Defelici A, Von Axell-Castelli I, Roscigno G. False HIV positivity in leprosy. Abstract 13th International Leprosy Congress 1988.

96 Burgess P J, Fine PEM, Ponnighaus JM, Draper C. Serological tests in leprosy. The sensitivity, specificity and predictive value of ELISA tests based on phenolic glycolipid antigens, and the implications for their use in epidemiological studies. Epidem Inf, 1988; 101: 159-71.

\section{La préparation d'une sérologie de HIV pour l'essai du vaccin contre la lèpre à Karonga, Malawi}

\section{A SHAW, A C TURNER, J M BLACKWELL, P E M FINE ET J M PONNIGHAUS}

Sommaire - Comme partie de l'essai d'un vaccin contre la lèpre qui procède en ce moment au distrit de Karonga, au nord du Malawi, il est essentiel d'établir si la présence dans la population du HIV 
(virus d'immunodéficience humaine) est en train d'influencer le taux de fréquence ou la présentation clinique de la lèpre ou l'éfficacité des vaccins sous essai. Pour obtenir l'information nécessaire il fallait développer un protocole d'analyse de HIV rapide et économique qui pourrait être exécuté dans un laboratoire rural et qui serait résistant aux conditions ambientales variables. Cet article rapporte sur l'étape développement/évaluation d'un protocole d'essais multiples basé sur des kits d'agglutination de particules et kits ELISA de détection d'anticorps anti-HIV disponibles dans le marché. Le développement initial du protocole consistait en l'évaluation à Londres de plusieurs kits avec une série de sérums provenant de l'Afrique et ailleurs, avant de soumettre 1455 sérums aux essais sur le terrain à Malawi. Ces sérums comprenaient 184 provenant de patients de lèpre et 60 de patients de syphilis pour vérifier s'il y avait des réactions croisées. Suivant le protocole développé, tous les sérums sont analysés initiellement avec l'ELISA indirect (Organon) et avec une modification rapide et économique de l'essai d'agglutination de particules par Serodia. Les sérums positifs sont re-analysés avec un ELISA compétitif (Wellcome ou Boerhing) et l'essai normal d'agglutination de particules (Serodia). La validité de ce protocole d'essais multiples a été confirmée par l'utilisation (à Londres) de la technique "Western blotting" sur un grand nombre de sérums positifs et négatifs provenants de Malawi. Des facteurs qui influencent la sélection des kits, et les problèmes associés avec des kits individuels sont discutés. Bien que le protocole d'essais multiples développé spécifiquement pour le Malawi pourrait bien ne pas être valable pour chaque projet, le principe de développer des alternatives au "Western blotting" qui soient économiques doit être une consideration importante pour n'importe quelle enquête sur le terrain concernant le HIV.

\section{La preparación de una serología del HIV para el ensayo de una vacuna contra la lepra en Karonga, Malawi}

\section{A SHAW, A C TURNER, J M BLACKWELL, P E M FINE Y J M PONNIGHAUS}

Resumen - Como parte de la prueba de una vacuna contra la lepra que esta teniendo lugar en el distrito de Karonga, al Norte de Malawi, es esencial el determinar si la presencia en la población del HIV (virus de inmunodeficiencia humana) afecta el índice de frecuencia o la presentación clínica de la lepra o la eficacia de las vacunas en prueba. Para obtener la información adecuada, hizo falta desarrollar un protocolo rápido y económico de prueba de HIV, que se pudiera hacer en un laboratorio rural y que resistiera condiciones ambientales variables. Este artículo informa acerca de la etapa desarrollo/evaluación de un protocolo de pruebas múltiples basado en equipos de aglutinación de partículas y equipos ELISA de detección de anticuerpos anti-HIV disponibles en el mercado. Este protocolo se desarrolló inicialmente probando varios equipos en Londres con una serie de sueros provenientes de Africa y de otros lugares y después llevando a cabo pruebas sobre el terreno con 1455 sueros en Malawi, que incluían 184 sueros de pacientes de lepra y 60 de pacientes sifilíticos para comprobar si había alguna reacción cruzada. Siguiendo el protocolo desarrollado, se prueban todos los sueros utilizando el ELISA indirecto (de Organon) y una modificación rápida y económica de la prueba de aglutinación de partículas de Serodia. Los sueros que den resultados positivos se vuelven a examinar utilizando un ELISA competitivo (de Wellcome o Boehring) y la prueba normal de Serodia de aglutinación de partículas. La validez de este protocolo de pruebas múltiples se confirmó en Londres utilizando la técnica de "Western blotting" sobre un gran número de sueros positivos y negativos procedentes de Malawi. Se discuten los factores que influenciaron la selección de los equipos, y los problemas que hubo con equipos individuales. Mientras que el protocolo de pruebas múltiples desarrollado específicamente para utilizar en Malawi puede no valer en todos los casos, el principio de desarrollar alternativas económicas al "Western blotting" es una consideración importante en todo estudio del HIV llevado a cabo sobre el terreno. 